REGIONAL STATISTICS, 2012, VOL. 2: 13-26 DOI: 10.15196/RS02102

\author{
KARIMA KOURTIT - PETER NIJKAMP - ANDREA CARAGLIU \\ - CHIARA DEL BO
}

\title{
Spatial Contextual Impacts on Business Performance of Dutch Firms
}

\begin{abstract}
Aims and scope
The literature on industrial innovation shows a remarkable pattern. In earlier contributions (see e.g. Schumpeter 1934) much attention has been given to the institutional and market conditions (for instance, competition) that acted as drivers for innovations by entrepreneurs. Innovations were mostly seen as necessary instruments to survive in a competitive economy.

In the 1980s much attention was also given to the economic impacts of industrial innovation, e.g. on labour markets, on regional disparities, or on economic growth. However, at the same time it was recognized that innovation is not 'manna from heaven', but the result of our deliberate actions, in both the public and the private sector. Against the background of endogenous growth theory, much attention was also paid to the impact of $\mathrm{R} \& \mathrm{D}$, education, training, and subsidies on the innovation intensity of entrepreneurs. Entrepreneurial innovation was no longer seen as a 'fate', but as an opportunity to be created by active entrepreneurs.

In the past two decades, the regional and urban context of innovation has received much interest. The popularity of concepts such as 'regional innovation systems' or 'open innovation systems' has prompted an avalanche of studies on the knowledge-based society, on the high-tech economy, and in more recent years on the creative economy (see e.g. Kourtit et al. 2011). The spatial dimension of the innovation society has increasingly been put at the centre of scientific research. In particular, the socioeconomic, technological, institutional, and cultural conditions of cities and regions have been given much attention from the perspective of drivers or facilitators of economic growth. In parallel, the local socio-economic impacts of innovation have also become a centrepiece of recent scientific research in innovation.

The present study aims to highlight the drivers and impacts of innovative activities in the high-tech sectors from the perspective of local and regional dimensions. To that end, an extensive dataset on Dutch high-tech firms has been created and investigated. The attention will in particular be focused on a triple-layer analytical framework: the spatial context, the industrial context, and the entrepreneurial context.

This paper is organized as follows. After this introductory section, we will provide in Section 2 more information on the empirical database. Next, Section 3 will describe the regional and industrial context, where human capital, urbanization, and social capital will extensively be discussed. Section 4 will then analyse the regional variation in the determinants of the economic performance of the firms concerned, while Section 6 will offer concluding remarks.
\end{abstract}




\section{Description of the sample and methods for data collection}

The present paper aims to offer an evidence-based framework for studying the relationship between the performance of high-tech firms and spatial context in the Netherlands. To that end, data was collected via 244 interviews among managers, CEOs, directors etc. working for 61 Dutch high-tech firms. This individual micro data set is next merged with regional attributes and characteristics, collected at the $\mathrm{COROP}^{1} / \mathrm{NUTS} 3$ level. To systematize our data set a triple-layer structure is designed, with a regional level, an industrial level, and a firm level (see Figure 1).

A multi-level approach to firm performance

Figure 1

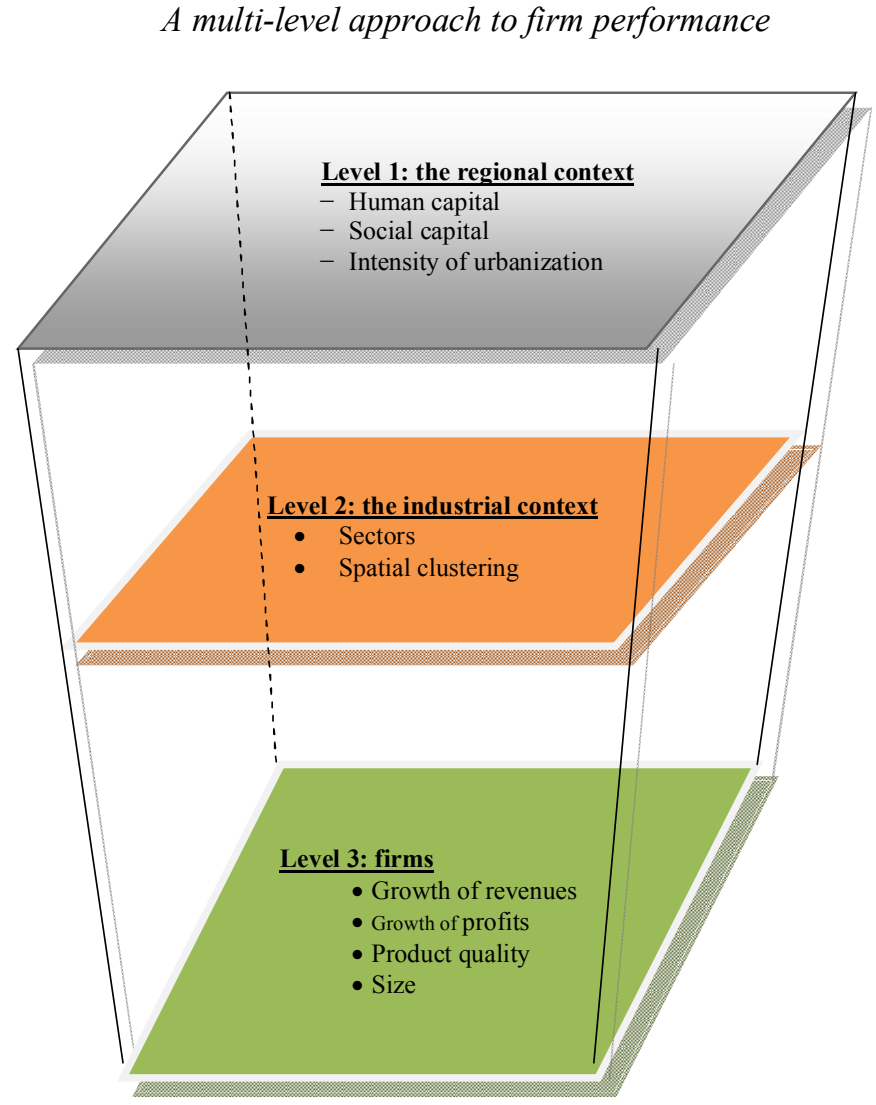

Source: Authors' elaborations.

1 COROP ("Coördinatiecommissie Regionaal Onderzoeksprogramma") regions are statistical areas whose data are collected by the Dutch Central Bureau for Statistics (CPB). At the European level, and, therefore, for EUROSTAT purposes, they correspond to the NUTS3 level. 
The above presented multi-level approach to firm performance was inspired by the recently developed 'Flying Disc' multilevel model by Kourtit and Nijkamp (2012). According to these authors, the architecture of the 'Flying Disc' model of firms' business performance in geographical space 'serves as a strategic navigation instrument that maps out main directions in a comprehensive micro-meso framework, which includes an integrated set of essential locational factors (inputs) in core geographical zones, as well as linkages that determine a firm's micro-business performance (outputs)'. This framework addresses dynamic force fields that occur in cities and regions. This framework is structured to reflect the functional mechanism through which firms, in terms of competitive behaviour, optimize their spatial economic performance. This leads essentially to a conceptual complex and multilevel model. Figure 1 shows that a decomposition of these force fields leads to new and functionally distinct constructs, where each construct is mutually connected with the others. Thus, our multi-level approach is based on a ramification of forces and regional and industrial determinants, that altogether make up an integrated system, which may matter in achieving a higher business performance and success. Each type of force and construct can be associated with a collection of relevant research challenges in order to trace the regional key drivers of the urban agglomeration dynamics that exert a decisive impact on the XXPQP (maximum contribution to productivity, quality, and profitability) of firms. This performance framework is largely similar to the XXQ concept; see Nijkamp (2008). Clearly, this framework can be transformed into an operational measurement model (using actual data) to evaluate and rank the comprehensive performance of innovative firms in the high-tech sector, provided detailed assessments of geographical and urban determinants are available from reliable statistics.

\section{The regional and industrial context}

\section{Introduction}

In this section, we will organize the dataset in a form that is appropriate for statistical analysis. The firm-level data described in the previous section have been collected by interviewing firms in 18 COROP (NUTS3) Dutch regions, out of 39. The localization of the regions where the sampled firms belong to is shown in Figure 2.

The regional sample covers 54 per cent of the total Dutch population, and 56 per cent of total value added. ${ }^{2}$ In the regions belonging to the sample, labour productivity is on average 2 per cent higher than the Dutch average. Within the sample of regions where the interviews took place, labour productivity differentials are much larger: the most productive region is 75 per cent more productive than the Dutch average, while the least productive suffers from a 40 per cent productivity gap with respect to the same mean value. 
COROP (NUTS3) regions in the Netherlands where at least one firm has been interviewed: the spatial context

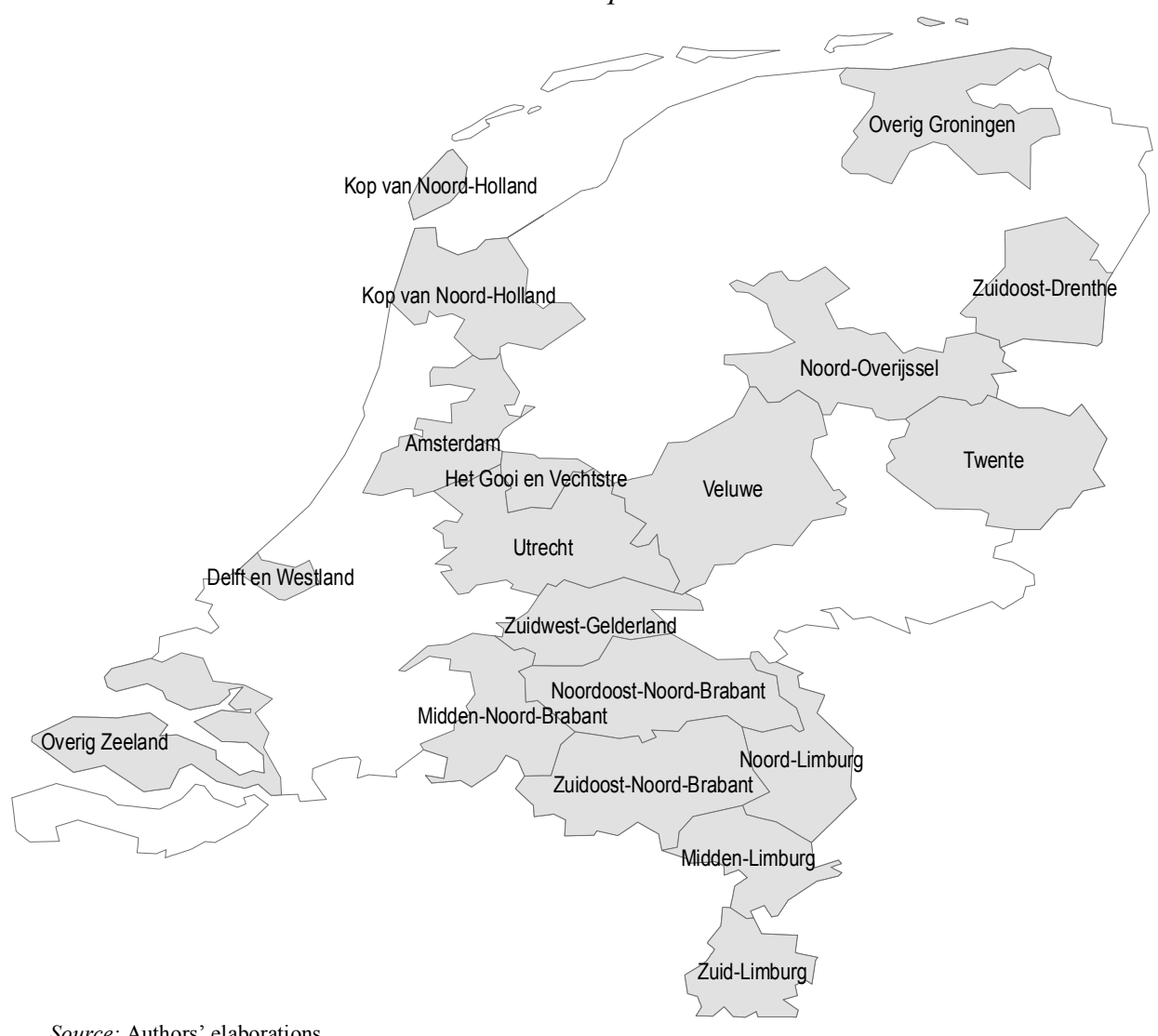

Source: Authors' elaborations.

All firms interviewed belong to medium-high and high-tech industries (Figure 3). In particular, a large majority of firms are active in the high-tech machinery sector, with ICTs (Information and Communication Technologies) and chemicals as the second most common sectors (see also Kourtit et al. 2013). 
Frequency of the interviewed firms per industry

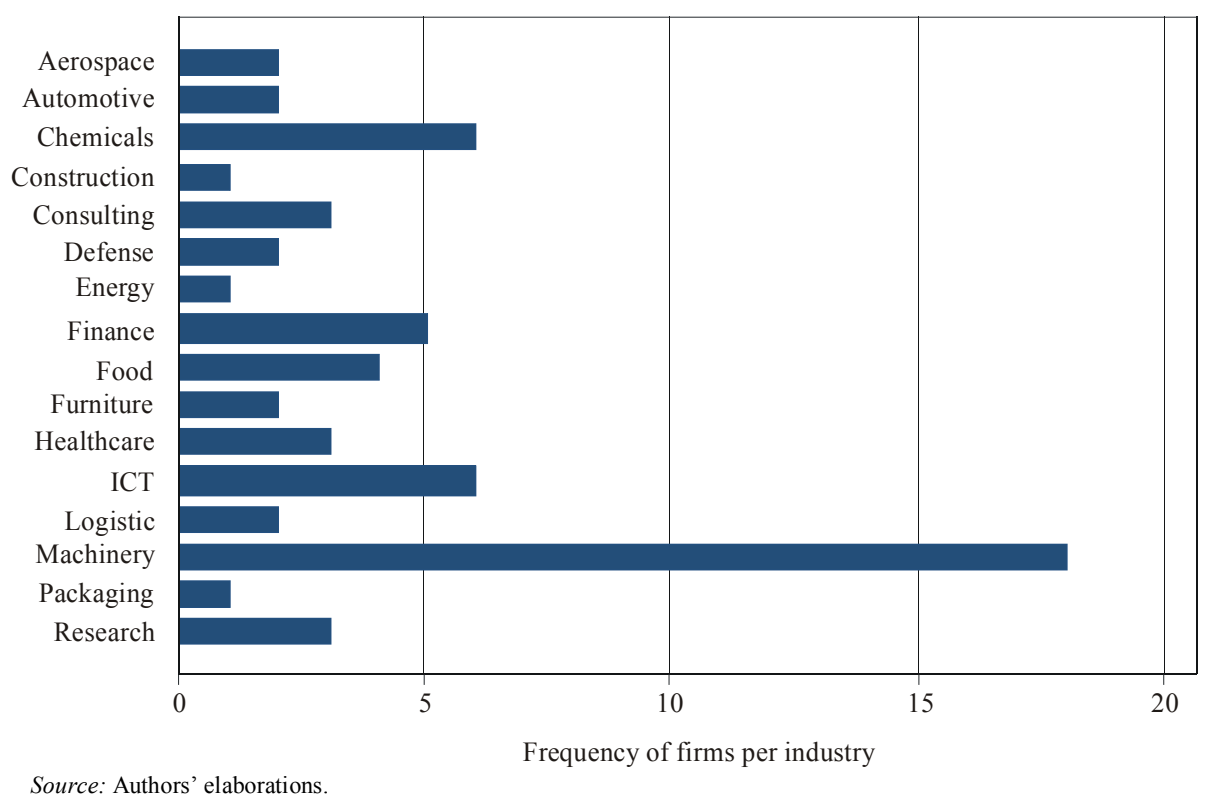

Because of the increasing relevance of the regional context for firms' performance (Section 1), the present section presents an overview of the main elements characterizing the regional context where the interviewed firms are active. In particular, Section 3.2 discusses the regional endowment of human capital; Section 3.3 shows how strongly each region hosting at least one interviewed firm is urbanized; and Section 3.4 finally, discusses the wealth of social capital of the regions of the sampled firms. These three elements represent the three core characteristics differentiating regions where the interviews have been carried out, and provide, along with the industrial dimension, the framework for firms' activities and performance. Although in the present paper these dimensions are only analysed and described, they can be used as the ideal setting of an econometric evaluation of firms' performance.

\section{Human capital}

At all spatial scales, the endowment of human capital has been found to be remarkably growth-enhancing, in particular through the positive impact on firm performance (Becker 1964, Mincer 1974). Substantial empirical evidence of this claim is also available at the firm level (Crook et al. 2011, for instance, represent a recent convincing meta-analysis on this issue), stressing the importance of an educated and high-skilled workforce for firms' performance.

More recently, because of the increasingly widespread availability of an educated labour force in most Western countries, complex forms of human capital, which move beyond the pure level of education-based definitions provided by earlier literature, have 
been proposed and analysed. Recent contributions (Wößmann 2003, Vandenbussche et al. 2006, Caragliu et al. 2012) posit that high-level professions, creative capital, and urban knowledge capital are increasingly relevant in determining urban performance.

In order to properly capture the level of human capital in Dutch COROP regions, a measure comprising both traditional (viz. level of education) as well as more recent (i.e. the share of high-level professionals, the wealth of creative capital, and the urban knowledge capital) approaches to human capital is built, by aggregating human capital indicators via a Principal Component Analysis. ${ }^{3}$ The resulting human capital indicator is mapped, in Figure 4 for the regions in the sample.

Figure 4 clearly shows a north-west-south east axis of high-human capital regions, with a strong concentration of high values within the Randstad conurbation. ${ }^{4}$ More remote areas, such as the country's north-east and the regions bordering Germany, present instead a less human-capital rich environment. This issue can be further analysed by inspecting the regions' urbanization level (Section 3.3).

\section{Intensity of urbanization}

Figure 5 represents the intensity of urbanization for each area within COROP regions. ${ }^{5}$ According to the classical definition provided in Hoover (1936), in fact, firms located in denser urban areas enjoy productivity increases because of cost savings, external both to the firm and to the industry; these are labelled as urbanization economies. Indeed, the map represented in Figure 5 clearly matches the information commented on in Section 3.2: firms located in the highly urbanized Randstad area also enjoy, ceteris paribus, a better access to human capital, which is typically concentrated in large metropolitan areas. Whether both these productivity advantages are beneficial to the firms' focus on short- and long-term performance indicators will be examined in Section 4.

3 The details of the performed PCA and a thorough description of the human capital indicators used can be found in Kourtit et al. (2013).

4 The Randstad is one of the largest conurbations in Europe. It comprises the four largest Dutch cities (viz. Amsterdam, Rotterdam, The Hague, and Utrecht), and, according to the 2011 Randstad Monitor, it hosts more than 6.8 million people, which represents about 40 per cent of the total Dutch population.

5 The data here employed classify areas according to a five-tier classification (from top to bottom, very strongly urbanized through not urbanized). Data are collected by aggregating the density of registered addresses in $500 \mathrm{~m}$-sided squares. These data, along with the COROP/NUTS3 boundaries, are represented in Figure 5. For more details on the methods for data collection, see also CBS (2008). 
The regional context: human capital

Figure 4

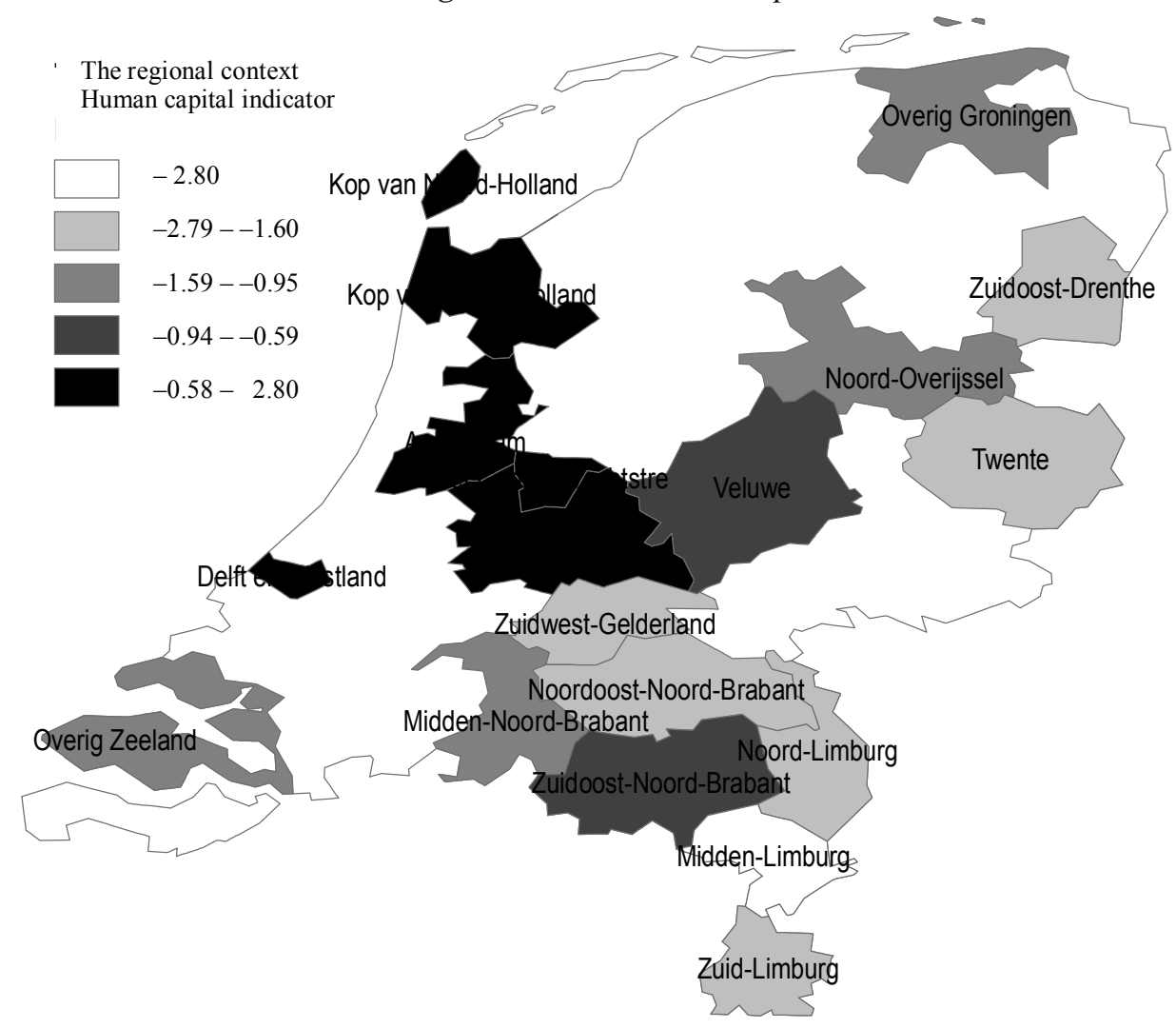

Source: Authors' elaborations.

Social capital

Social capital (Putnam 2000, Putnam et al. 1993, Fukuyama 1995, Bourdieu 1983, among many others) refers to the set of norms, networks, and institutions forming the glue of a society. Since firms located in a region with a high level of social capital are expected to reap the benefits in terms of productivity advantages (Bosma et al. 2004), the regional endowment of social capital represents a crucial asset for firms' performance. Figure 6 maps social capital values in the 18 analysed COROP regions. ${ }^{6}$

6 The variable being portrayed in Figure 6 results from a PCA performed on trust, norms, and networks COROP regions indicators as explained in Kourtit et al. (2013). 
The regional context Intesity of urbanization

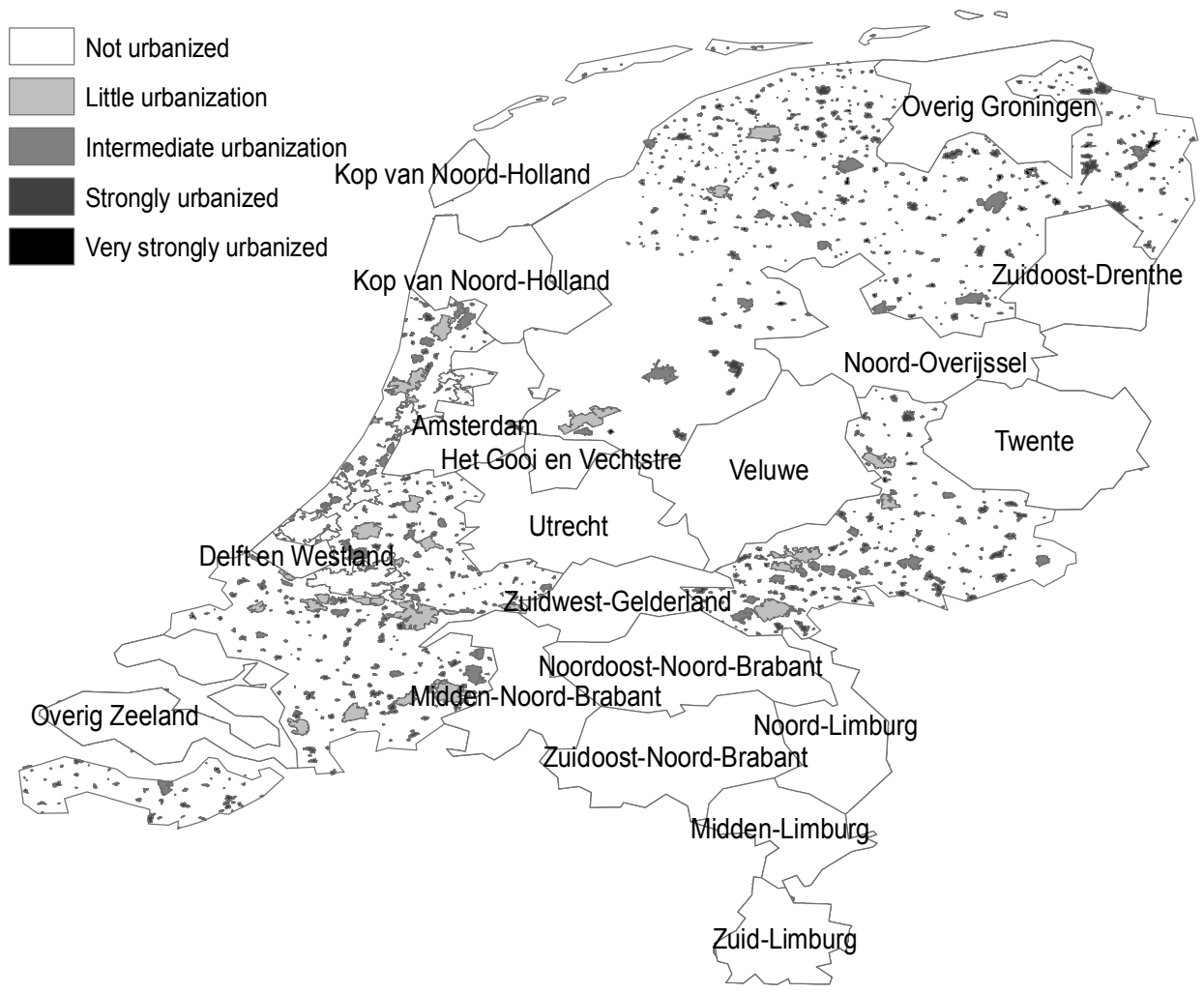

Source: Authors' elaborations.

Figure 6 displays a concentration of high social capital values in South-Eastern COROP regions, and in regions with relatively low levels of urbanization, as exemplified in Figure 5. Whether firms enjoy more relevant productivity advantages from high levels of social of human capital, or from being located in a more urbanized area, requires further research.

\section{Classifying regional variations in the determinants of firm performance}

Section 3 has provided a clear description of the relevant spatial clustering of regionspecific firm performance determinants in our sample. An a-spatial positive association between firm performance indicators and such characteristics suggests that firm 
performance, or objectives, could also be spatially clustered. In this Section, we inspect such association more formally.

Figure 6

The regional context: social capital

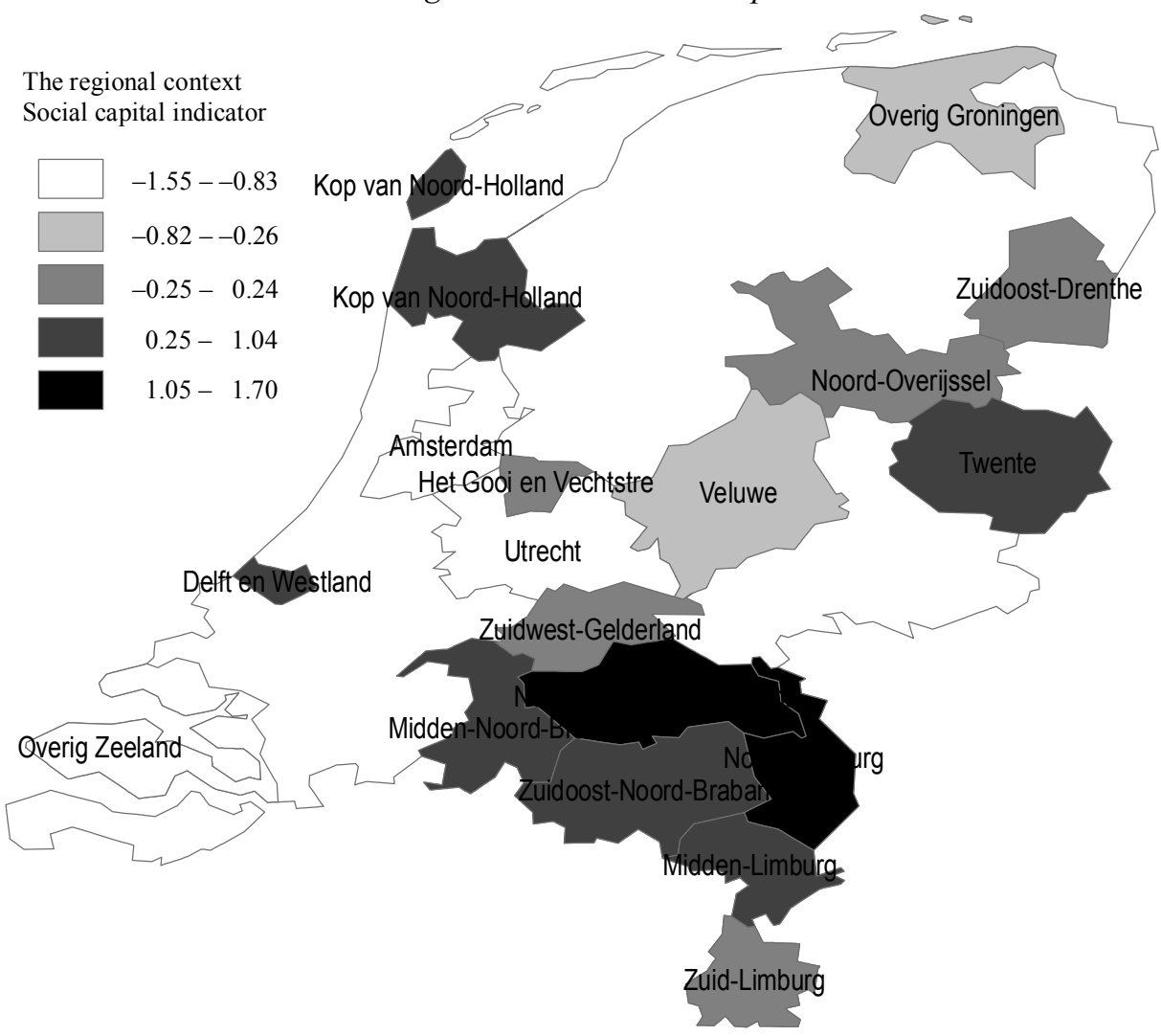

Source: Authors' elaborations.

Table 1 begins by presenting the extent to which firm objectives, as stated in the questionnaires, referred to in Section 2, are clustered in COROP regions. In the last row, we also present the ratio of the highest to the lowest mean value recorded for all firm objectives indicators considered. We focus in particular on the following goals or objectives for the firm: growth of revenues, growth of profits and product quality, and we report the mean value of the importance of each objective at the firm level (on an increasing scale from 1 to 5) in each COROP region.

The evidence presented suggests that while profits (second indicator, Table 1) represent a common goal, with a similar relative importance for most firms, irrespective of their location, the growth of revenues (first indicator, Table 1), and product quality (third indicator, Table 1) present relevant spatial clustering. Focusing on product quality, this final goal for firms' objective function is characterized by wide spatial differences. This is further corroborated, from results in the last row of Table 1, by a relevant 
difference (quantified by a ratio of 5) between the region in which such objective is least important (viz. Zuidwest-Gelderland), and the regions in which it is of maximum relevance (i.e., the NUTS3 regions of Overig Groningen and Veluwe).

Table 2 classifies the same firm objectives presented in Table 1 by firm size. Interestingly, it appears that smaller firms not only present a higher focus on short-term objectives, such as the mean growth of revenues or profits (as suggested in several previous contributions; see for instance Audretsch, 1991), but also, although less significantly so, they consider investing in increased product quality a relevant objective in their activities. ${ }^{8}$

Table 1

Spatial clustering of firm objectives in Dutch COROP regions

\begin{tabular}{|c|c|c|c|c|}
\hline Name of COROP/NUTS3 region & NUTS3 code & $\begin{array}{l}\text { Mean growth of } \\
\text { revenues }\end{array}$ & $\begin{array}{l}\text { Mean growth of } \\
\text { profits }\end{array}$ & $\begin{array}{l}\text { Mean product } \\
\text { quality }\end{array}$ \\
\hline Overig Groningen & NL113 & 4.00 & 4.00 & 5.00 \\
\hline Zuidoost-Drenthe & NL132 & 4.00 & 4.00 & 3.00 \\
\hline Noord-Overijssel & NL211 & 4.00 & 4.00 & 3.00 \\
\hline Twente & NL213 & 3.00 & 4.00 & 3.00 \\
\hline Veluwe & NL221 & 4.00 & 4.00 & 5.00 \\
\hline Achterhoek & NL222 & 3.00 & 3.00 & 2.00 \\
\hline Arnhem/Nijmegen & NL223 & 4.00 & 4.00 & 3.00 \\
\hline Zuidwest-Gelderland & NL224 & 2.00 & 2.00 & 1.00 \\
\hline Utrecht & NL310 & 2.96 & 2.83 & 2.94 \\
\hline Kop van Noord-Holland & NL321 & 4.00 & 4.00 & 4.00 \\
\hline Amsterdam & NL326 & 2.86 & 3.14 & 3.00 \\
\hline Het Gooi en Vechtstre & NL327 & 3.50 & 4.00 & 3.50 \\
\hline Agglomeratie Leiden & NL331 & 1.00 & 4.00 & 4.00 \\
\hline Delft en Westland & NL333 & 3.00 & 3.00 & 3.00 \\
\hline Rijnmond & NL335 & 2.50 & 2.50 & 2.00 \\
\hline Overig Zeeland & NL342 & 3.00 & 3.00 & 4.00 \\
\hline Midden-Noord-Brabant & NL412 & 4.00 & 3.33 & 3.33 \\
\hline Noordoost-Noord-Brabant & NL413 & 4.00 & 4.00 & 4.00 \\
\hline Zuidoost-Noord-Brabant & NL414 & 3.23 & 3.38 & 3.54 \\
\hline Noord-Limburg & NL421 & 3.00 & 4.50 & 3.50 \\
\hline Midden-Limburg & NL422 & 3.00 & 4.00 & 3.00 \\
\hline Zuid-Limburg & NL423 & 2.50 & 4.00 & 3.00 \\
\hline Ratio of highest to lowest & & 4.00 & 2.25 & 5.00 \\
\hline
\end{tabular}

Source: Authors' elaborations.

8 Remarkable statistical significance is associated with the different relevance of revenues growth, (the p-value of the classical t-tests for differences in group means is equal to 0.06 ). All other t-tests turn out to be marginally not significant. 
Firm objectives and firm size

\begin{tabular}{|c|c|c|c|}
\hline Firm size & Mean growth of revenues & Mean growth of profits & Mean product quality \\
\hline Small & 3.26 & 3.41 & 3.14 \\
\hline Large & 2.79 & 3.36 & 3.11 \\
\hline Ratio of highest to lowest & 1.17 & 1.01 & 1.01 \\
\hline
\end{tabular}

Table 3 classifies the three-abovementioned firm objectives according to the regions' level of human capital, measured by the indicator described in Section 3.1. In this case, and somewhat unexpectedly, firms located in regions with a lower than average level of human capital pay more attention to profits growth and product quality, and significantly so. ${ }^{9}$

Table 3

Firm objectives and the region's human capital

\begin{tabular}{l|c|c|c}
\hline Wealth of human capital & Mean growth of revenues & Mean growth of profits & Mean product quality \\
\hline Low & 3.28 & 3.62 & 3.38 \\
High & 2.97 & 3.19 & 2.91 \\
\hline $\begin{array}{l}\text { Ratio of highest to lowest } \\
\text { Source: Authors' elaborations. }\end{array}$ & 1.10 & 1.14 & 1.16
\end{tabular}

This piece of evidence can be usefully confronted with the same type of test performed by considering the intensity of urbanization of the region where the firm is located. From results presented in the vast literature explaining how skilled workers concentrate in urban areas (e.g. Moretti 2004, among countless others), one would expect more urbanized areas to host firms committing more to all the three objectives, above all product quality.

Table 4 shows instead that strongly urbanized areas host firms which pay the lowest attention to all three objectives. The highest focus on revenues growth is registered for areas with an intermediate degree of urbanization, which typically represent companies active in mature industries, looking for residential locations with relatively lower rent levels, in order to reap the productivity benefits stemming from large-scale production. On the contrary, firms located in denser urban areas may actually look for different objectives, mostly related to knowledge access, as suggested also by the knowledge spillovers (Anselin et al. 1997) and the milieu innovateur (Camagni 1991) literature. Such statements can be further crosschecked in Figure 7 below. 
Firm objectives and the region's level of urbanization

\begin{tabular}{l|c|c|c}
\hline \multicolumn{1}{c|}{ Level of urbanization } & Mean growth of revenues & Mean growth of profits & Mean product quality \\
\hline Not urbanized & 3.00 & 3.00 & 4.00 \\
Little & 3.21 & 3.43 & 2.86 \\
Intermediate & 3.50 & 3.88 & 3.38 \\
Strong & 3.31 & 3.69 & 3.38 \\
Very strong & 2.33 & 2.33 & 2.66 \\
\hline Ratio of highest to lowest & 1.50 & 1.66 & 1.50
\end{tabular}

Source: Authors' elaborations.

The apparently contradictory results obtained here, viz. that firms located in moderately urbanized areas and in areas with a lower than average human capital, seem to be significantly more interested in profits and revenues growth, and in product quality, deserves further research efforts.

Figure 7

Firm objectives and the region's level of urbanization

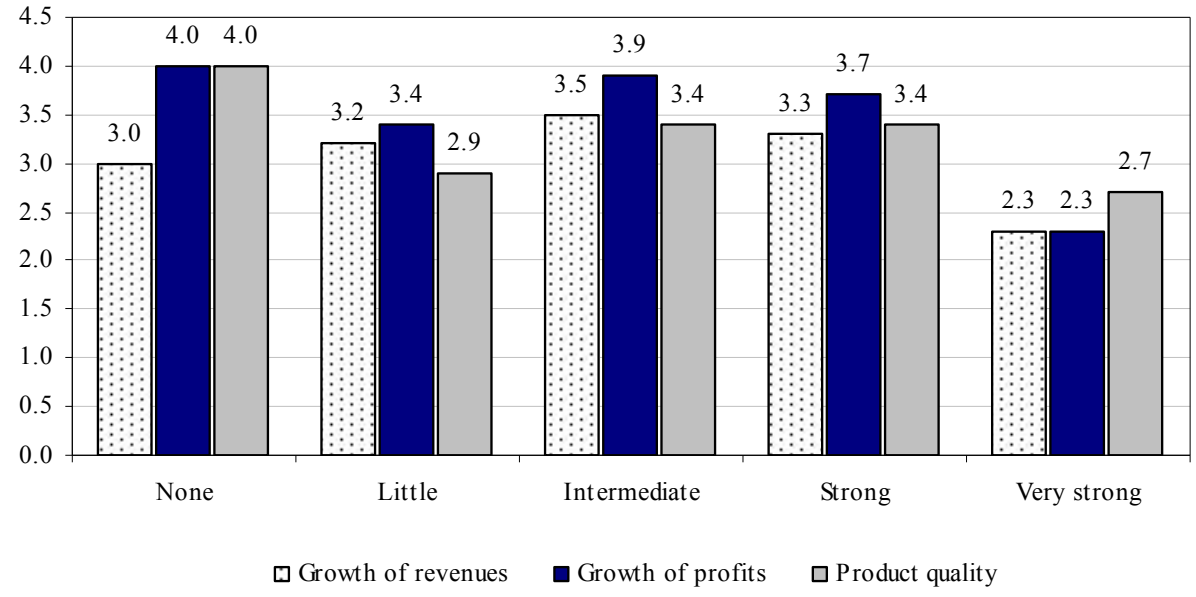

Source: Authors' elaborations.

Finally, Table 5 presents similar statistics, with a classification of firm objectives by levels of regional social capital.

Table 5

Firm objectives and the social capital

\begin{tabular}{l|c|c|c}
\hline Wealth of social capital & Mean growth of revenues & Mean growth of profits & Mean product quality \\
\hline Low & 2.87 & 3.23 & 2.97 \\
High & 3.37 & 3.57 & 3.30 \\
\hline Ratio of highest to lowest & 1.17 & 1.11 & 1.11 \\
\multicolumn{2}{c|}{ Source: Authors' elaborations. } & &
\end{tabular}


In this case, the results are in line with previous findings on the positive association between social capital (in the form of stronger weak ties, higher trust, and more intense sociability). For all three firm objectives analysed here, the results from the plant-level sample observed suggest that firms pay uniformly more attention to profits and revenues growth, and product quality, as the level of social capital of the region in which they are located increases.

This last result is however slightly at odds with the previously described findings on urbanization levels and human capital. In fact, social capital is consistently found to be positively associated (with a one-to-one relationship) with human capital (Coleman 1988). Societies with a more educated labour force seem to enjoy higher levels of trust, while the reverse is also true (i.e., societies with better weak ties/stronger bonds and higher trust tend to invest more time and money in accumulating human capital).

The picture stemming from the analysis of the industrial and regional environments where the firms interviewed are active clearly calls for a deeper analysis of the causal direction of the relations depicted here. Particular attention should finally be paid to the level of analysis where each impact between firm performance determinants, profit and revenues growth, and product quality achievements, takes place.

\section{Concluding remarks}

Spatial dynamics is the outcome of a complex socio-economic and technological force field, with a complex ramification of micro-based motives (e.g. entrepreneurial performance strategies) and macro-oriented (or meso-oriented) contextual drivers. The study of the nexus firms-regions calls for a thorough statistical data collection and advanced statistical analyses.

The present analysis, using the Netherlands as a case study, aims to identify the determinants and success factors of competitive innovation strategies of high-tech firms. Their locational behaviour (either the search for new locations or the decision to stay where they are) appears to be a key factor for their performance. Clearly, location does not refer here to the specific locality of a firm, but also to the broader urban regions and spatial networks in which a firm has to operate. Our study offers an evidence-based illustration of the great importance of local and regional conditions for firms' strategies and behaviour.

It should be added that there is much scope for a further enhancement of our insights into the drivers and effects of spatial dynamics. Systematic database collection at a micro (firm) level, conceptualization of the various forces at work (in a multi-level configuration), and development of advanced statistical-econometric tools that are fit for purpose are indispensable for new insights into a complex space-economy.

\section{REFERENCES}

Anselin, L. - Varga, A. - Acs, Z. (1997): Local geographic spillovers between university research and high technology innovations. Journal of Urban Economics 42 (3): 422-448.

Audretsch, D. (1991): New firm survival and the technological regime. Review of Economics and Statistics 73 (3): 441-450. 
Becker, G. S. (1964): Human capital: a theoretical and empirical analysis, with special reference to education, Chicago (IL): University of Chicago Press.

Bosma, N. - van Praag, M. - Thurik, R. - De Wit, G. (2004): The Value of Human and Social Capital Investments for the Business Performance of Startups. Small Business Economics 23(3): 227236.

Bourdieu, P. (1983): Ökonomisches kapital, kulturelles kapital, soziales kapital. In: Kreckel, R. (ed.) Soziale Ungleichheiten (Soziale Welt, Sonderheft 2). pp. 183-98. Otto Schartz \& Co., Goettingen.

Camagni, R. (1991): Local milieu, uncertainty and innovation networks: towards a new dynamic theory of economic space. In: Camagni, R. (ed.) Innovation networks: spatial perspectives. Belhaven Press, London.

CBS (Centraal Bureau voor de Statistiek) (2008): Bevolkingskernen in Nederland, 2008. Retrieved online on Oct 12, 2012 at the URL http://www.cbs.nl/nl-NL/menu/themas/dossiers/nederland-regionaal/ publicaties/geografische-data/archief/2012/2010-bevolkingskernen-in-nederland-2008.htm.

Coleman, J. S. (1988): Social capital in the creation of human capital. American Journal of Sociology 94 (Supplement): S95-S120.

Crook, T. R. - Todd, S. Y. - Combs, J. G. - Woehr, D. J. - Ketchen , D. J. (2011): Does human capital matter? A meta-analysis of the relationship between human capital and firm performance. Journal of Applied Psychology 96 (3): 443-456.

Hoover, E. M. Jr. (1936): The measurement of industrial localization. The Review of Economics and Statistics 18 (4): 162-171.

Fukuyama, F. (1995): Trust: the social virtues and the creation of prosperity. Free Press, New York (NY).

Kourtit, K. - Nijkamp, P. - Stough, R. (eds.) (2011): Drivers of Innovation, Entrepreneurship and Regional Dynamics. Springer, Berlin.

Kourtit, K. - Nijkamp, P. (2012): In Search of Creative Champions in High-Tech Spaces; A Spatial Application of Strategic Performance Management. Journal of Regional Science (forthcoming).

Kourtit, K. - Nijkamp, P. - Caragliu, A. - Del Bo, C. (2013): Impacts of Multi-Level Capital Resources on Local Business Performance. In: Kourtit, K. - Nijkamp, P. - Stimson, R. (eds.) Applied Modelling of Regional Growth and Innovation Systems. Springer, Berlin. (forthcoming).

Mincer, J. (1974): Schooling, experience and earnings. Columbia University Press, New York (NY).

Moretti, E. (2004): Estimating the social return to higher education: evidence from longitudinal and repeated cross-sectional data. Journal of Econometrics 121 (1-2): 175-212.

Nijkamp, P. (2008): XXQ Factors for Sustainable Urban Development: A Systems Economics View. Romanian Journal of Regional Science 2 (1): 1-34.

Putnam, R.D. (2000): Bowling alone: the collapse and revival of American community. Simon \& Schuster, New York (NY).

Putnam, R.D. - Leonardi, R. - Nanetti, R.Y. (1993): Making democracy work: civic traditions in modern Italy, Princeton University Press, Princeton (N.J).

Schumpeter, J. (1934): The Theory of Economic Development. Harvard University Press, Cambridge MA.

Vandenbussche, J. - Aghion, P. - Meghir, C. (2006): Growth, distance to frontier and composition of human capital. Journal of Economic Growth 11 (2): 97-127.

Keywords: innovation, high-tec, clusters, performance.

Abstract

This paper offers a statistical analysis of the regional contextual drivers and aspects of innovative firms in the high-tech sector in the Netherlands. Data are collected by means of 244 interviews among actors working for 61 Dutch high-tech firms. This individual micro data set is next merged with regional attributes and characteristics, collected at the COROP (NUTS3 level) in the Netherlands in order to analyse the relationship between the economic performance of individual firms and the broader regional economic environment. 